\title{
Čas generací
}

\section{The Time of Generations}

\author{
Michael Corsten
}

\begin{abstract}
This article develops a discursive-pragmatic concept from Mannheim's theory of generation, especially from his idea of generation as an actuality which emphasizes the collective cognitive background or horizon of a generation. The author also discusses the emergence of such a cognitive background as dependent on a coincidence of different time perspectives, which are biographical, historical and generational times. To explicate the discursive practice of generations the concepts of "historical time" (Robinson), "historical semantics" (Luhmann), and "cultural circles" are introduced. The autor works out an understanding of the "problem of generation" that should lead to empirical investigations on this topic by using interpretive and reconstructive research methods.
\end{abstract}

KEY WORDS cultural circles, discursive practice, generational background, historical semantics, historical time

\section{Úvod}

Téma generací zažilo v posledních pěti či deseti letech renesanci. Nejvýznamnějším důvodem tohoto vývoje je krize kolektivních identit, zapříčiněná množstvím okolností a podmínek. První z nich představuje proces „individualizace“ (Beck 1997) v rozvinutých společnostech vyznačujících se „reflexivní modernizací“ (Beck a kol. 1994), v němž oslabil význam kategorií jako je „sociální původ“ pro vysvětlování kolektivních identit, žitých prostředí a sociálních hnutí. Druhým důvodem je vymizení ústředních sociálních konfliktů, které rozdělovaly společnosti na antagonistické vrstvy, tj. třídy. Třetí důvod související s uvedenou krizí představuje konec socialismu jako alternativního modelu modernizace, doprovázeného tvrzeními o „konci ideologii“ či „konci historie“. Takže, jestliže zmizely „staré“ kolektivní identity, existují nové nebo alternativní identity, které mohou ony staré nahradit? V této souvislosti se jako nové klasifikační znaky objevují věk a generace. Za prvé, věk je v každém případě důležitým strukturujícím konceptem života jedince a jeho životní historie. To v důsledku znamená, že za předpokladu standardizovaných životních drah tvoří věkové kohorty kolektivní agregáty sociálně strukturovaných životních historií. Za druhé, věk může sloužit jako ukazatel sociální diferenciace, a tím i sociálních konfliktů - nového „generačního konfliktu“ ve „stárnoucí společnosti“. Je však důležité si připomenout, že „generační propast“ má v sociálních (kulturních) vědách a ve filosofii dlouhou tradici a že tento termín je

Sociální studia. Fakulta sociálních studií Masarykovy univerzity, 1-2/2007. S. 45-65. ISSN 1214-813X.

1 Překlad převzat z: Corsten, M. 1999. „Time of Generations.“ Time \& Society, 8 (2): 249-272. (C) SAGE 1999. Publikováno se svolením Sage Publications Ltd., www.sagepublications.com 
také často používán v široké škále významů v každodenním životě. Proto se zde soustředím na problém historického ustavování generací jako kolektivních identit.

Následující oddíly se touto otázkou zabývají v šesti krocích. Ve stručném přehledu se v prvním oddíle pokusím odlišit různá pojetí generací, abych vyjasnil vztah mezi problematikou historických generací, na něž se soustředí tento článek, a zbývajícími výzkumnými problémy v této oblasti. Druhý oddíl se zabývá Mannheimovým klasickým řešením „sociologického problému generace“ (Mannheim 1952 [1928]). Karl Mannheim na jedné straně rozlišuje tři roviny, na nichž se mohou generace utvářet, a na straně druhé rozpracovává vzájemné působení těchto tří rovin ve svém vysvětlení „unifikujících faktorư“ generací. Jak zdůraznila Jane Pilcher (1994) ve svém nedávném článku, Mannheimovo dílo je stále „nedoceněným odkazem“. Právě to se pokouším demonstrovat ve třetím oddíle srovnáním dvou různých přístupů - modelu kohort a modelu prostředí. Mé srovnání se zaměřuje především na časovou perspektivu a socializační koncepty, které tvoří základ Mannheimova řešení. Nabízím vysvětlení s pomocí pojmu „historického času“ Joan Robinson (1963, 1979) a zpřesnění Mannheimova konceptu ,zkušenosti“ a jeho důsledků pro socializační teorii. Ve čtvrtém oddíle rozebírám a doplňuji Mannheimovo řešení, jež je do jisté míry omezeno jeho perspektivou „sociologie vědění“. Pro tyto účely, s odkazem na C. W. Milse (1963), Tima Danta (1991) a Jane Pilcher (1994), představuji význam „diskurzivních praktik“ jako sociálního rozměru, v němž mohou být sociálně-kognitivní jevy zakotveny a identifikovány. Za pomoci Luhmannova (1980) a Koselleckova (1969) konceptu „historické sémantiky“ mohu převést Mannheimův,,princip utváření generací“ do podoby diskurzivního modelu. Ale - na rozdíl od Luhmannovy systémové teorie komunikace - setrvávám u konceptu diskurzivní praxe založené na jednání, přičemž zdůrazňuji „,sociální okruhy“ či „osobní sítě“ coby nositele sémantiky. Za použití některých argumentů teoretiků modernizace poukazuji na období adolescence jako na biografickou fázi, v níž dochází k vyhraňování sociálních okruhů generačního diskurzu - z jedné mladé generace směrem k další. Skrze tato stádia je rekonstruován endogenní proces krystalizace generací. To ovšem vyvolává tři důležité otázky, jimž se věnuji v pátém oddíle tohoto př́spěvku.

(a) Jak jsou generace ohraničeny v čase? Jinými slovy proč se někteří lidé narodí př́liš brzy nebo př́liš pozdě pro to, aby mohli patřit do určité generace?

(b) Jak důležité jsou vztahy mezi různými generacemi a vztahy mezi určitými skupinami té samé generace?

(c) Jak může být vysvětleno kolektivní stárnutí generace?

Na tyto otázky odpovím za pomoci začlenění každého z uvedených témat do konceptu generačního diskurzu. V posledním, šestém oddíle pojednám o tom, jak představený koncept řeší problémy, které zůstaly v Mannheimově klasickém př́stupu otevřeny. Zdůrazním přitom skutečnost, že tento koncept nabízí teoretický rámec podporující empirický výzkum generačních diskurzů.

\section{Generace: pojem s množstvím významů}

Je obtížné obsáhnout ohromné množství sociologické literatury zabývající se tématem generací. Zaujímá různé teoretické př́istupy a pokrývá širokou škálu výzkumných oblas- 
tí - od antropologie přes rodinu, politickou a kulturní sociologii až ke studiím sociální nerovnosti. Tento text si neklade za cíl podat přesný výčet odlišných konceptů generace. Zaměřuje se spíše na teoretické ukotvení jevu historických či „politických generací“ (Preston 1927, Rintala 1962). Pro objasnění specifického rysu tohoto problému budu rozlišovat mezi třemi kategoriemi pojmu generace.

Za prvé, pojetí generace ve smyslu následnosti se datují zpětně až k latinskému původu slova, které znamenalo „plození“. Etymologicky je odvozeno z řeckého výrazu ,genesis“ a odkazuje ke genealogiím coby liniím původu. Následnost generací je tak založena na biologickém faktu zrození a smrti. Je spojena s otázkou sociální a kulturní reprodukce (Ryder 1980) „z generace na generaci“ (Eisenstadt 1959). Právě sem patří studie, které definují generace jako (usouvztažněné) linie původu, ale také výzkumy sociální reprodukce (Coleman 1995) a mezigenerační sociální mobility (Rolf Becker 1994). Z tohoto hlediska lze socializaci vnímat rovněž jako sociální dědictví - jako předávání norem a hodnot z rodičů na děti, včetně negativních příkladů, jakým je „mezigenerační cyklus týrání dětí“ (Zuravin a kol. 1996). Téma následnosti-reprodukce může být zobecněno z problematiky rodinného původu na širší otázku sociálních nástupnických linií, například generační posloupnosti určitých kvalifikovaných profesí, jakou je „druhá generace sociologü“ (Morgan 1994), imigrantů (Hill a Moreno 1996) či - jako v nedávných německých kanclérských volbách - politických vůdců. Tyto oblasti lze prozkoumávat $\mathrm{v}$ obou rovinách: jako proces strukturální reprodukce, kdy se nahrazuje určitá sociální pozice, a jako proces kulturní reprodukce coby předávání a/nebo proměny norem a hodnot.

Za druhé, souběžná existence různých generací (věkových skupin) v jedné společnosti současně předpokládá mezigenerační vztahy, což poukazuje na dvě další důležité oblasti. První je otázka vzájemné závislosti věkových skupin, spojená s otázkami směny neboli solidarity (Henk A. Becker 1993) a mezigenerační smlouvy (Kohli 1996); druhou je otázka různých náhledů na sociální život a čas v závislosti na různých momentech životní historie, jež se projevují v generačních propastech (Van-Wel 1994), konfliktech a konkurenci.

Za třetí, hovoříme-li o následnosti a vztazích mezi generacemi, předpokládáme, že generace existují jako specifické kolektivní identity. Kdyby tomu tak nebylo, bylo by možné nahradit výraz „generace“ „věkovou skupinou“ nebo něčím podobným. Můžeme se tedy vrátit k otázce, jak je možné definovat generace coby skupiny osob v průběhu historie neboli jinými slovy coby historické generace. Kolektivní identity byly tradičně definovány prostřednictvím následnosti, např́klad „politických generací“. Idea historických generací odkazuje k obecnější otázce. Jak si lidé, kteří byli narozeni a vychováni ve stejném časovém období, osvojují sdílené chápání své zkušenosti? Tento problém byl v poslední době zkoumán jako otázka „kolektivní paměti“ (Bodnar 1996, Braungart a Braungart 1986, Lang a kol. 1993, Schuman a Scott 1989) a jako přetrvávání politických či ideologických kolektivních přesvědčení (Alwin a kol. 1991, Schuman a kol. 1997). Koncept historických generací proto odkazuje k sociálnímu času. Generace sdílejí obrázek „své doby“ nebo scénář dramatu svého kolektivního vývoje v průběhu „své“ historické fáze.

Tento př́spěvek se zaměří na třetí otázku. Historické generace lze zkoumat dvěma způsoby. Uvedený pojem pojímá generace především jako technický termín, sloužící účelům empirického výzkumu. $Z$ tohoto hlediska je definován minimalisticky, vylučujíc předpoklady, 
které mají být potvrzeny $\mathrm{v}$ průběhu zkoumání. $\mathrm{V}$ tomto smyslu se pro nahrazení kategorie generace také často používá pojmu „kohorta“ (Ryder 1965, Glenn 1977). V případě kohort jsou zkoumány jednotky tvořené skupinami osob sdružených podle roku narození s ohledem na znaky, které mají společné. Mezi tyto vlastnosti mohou patřit objektivní sociální ukazatele, jako je úroveň vzdělání, profesní kvalifikace, rodinný stav nebo př́iem. Stejným způsobem však mohou být v př́ípadě kohort zahrnuty i subjektivní znaky, jako jsou postoje, hodnotová přesvědčení, preference nebo motivy. To umožňuje srovnání různých kohort ve stejném období jejich života, stejně jako srovnání charakteristik (kolektivního) životního běhu. Proto je některými autory používán pojem kohorty namísto pojmu generace, nebot' nabízí jasnější vymezení jeho rozličných významů (Ryder 1965, Glenn 1977, Kertzer 1983, Van den Broek 1994).

Druhá strategie rozvíjí emfatickou definici termínu „generace“. Cílem podobného teoretizování je rekonstruovat smysl sociálního dění, tak jak je př́tomen ve fenoménu každodenní kultury. Tato strategie chápe generaci nejen jako pouhou konstrukci sociologů, ale jako konstrukci sociálních, nebo spíše „institucionálních faktư“ (Searle 1995). ${ }^{2}$ Podle tohoto prístupu nejsou př́slušníci určité generace jednoduše definováni sociologicky odhalenou soustavou pravidel. Jejich kolektivně sdílené představy společné životní zkušenosti a společného časového rámce jejich života se stávají nezávislým sociálním faktem.

\section{Mannheimův odkaz}

Mannheimův pokus o sociologii vědění nakládá s rozměrem generačně-specifické zkušenosti svébytným způsobem. Přestože Mannheimův př́spěvek k tomuto tématu bývá vnímán jako klasické řešení „problému generací“, často bývá pojednáván jako svého druhu výjimka v rámci jeho širšího díla (Kettler a kol. 1984, Matthes 1985, Longhurst 1989). Tento dojem se potvrzuje, jestliže se podíváme na vývoj Mannheimova díla. $V$ jeho rané fázi nacházíme celou řadu esejů a nedokončených rukopisů zabývajících se kulturní filosofíi a sociologií vědění. Ve 30. a 40. letech, v knihách Ideologie a utopie (1929) a Člověk a společnost ve věku rekonstrukce (1941), vytvořil rozsáhlé studie obecně se zamýšlející nad kulturním a politickým vývojem moderní společnosti. Znovuobjevení raných prací během 80 . let a následná diskuse (Kettler a kol. 1984, Matthes 1985) posunuly do popředí jeho sociologii vědění. Závěrem této debaty bylo konstatování, že Mannheim zkoumal odlišné způsoby, jimiž lidé vytvářejí kolektivně sdílené vědění, přičemž hledal specifické konstelace, které napomáhají vzniku sociálního vědění. $\mathrm{V}$ tomto ohledu představuje generace takovou konstelaci, která vede $\mathrm{k}$ vytváření zvláštní formy kolektivně sdíleného vědění. Mannheim tak propojil zkoumání francouzských pozitivistů s myšlením německých romantiků, kdy se francouzští pozitivisté soustředili na

$2 \quad$ Z mého pohledu odkazují ontologické rozdíly v sociologických teoriích na dvě zmíněné strategie. První z nich zavrhuje pojem „ontologie“ sociálních faktů a spoléhá na stabilitu metodologických konceptů odvozených sociálními vědci. Je ontologicky indiferentní, ale epistemologicky rigidní. Druhá je latentně realistickou pozicí, která předpokládá, že vždy existují přinejmenším sociální praktiky, které jsou „před“ a které musí být výzkumníky rekonstruovány (Corsten 1998). 
analýzu objektivních faktorů a běhu událostí a němečtí romantici kladli důraz na myšlenkové postoje a kolektivní pocity.

Podle Mannheima se kolektivní soudržnost generace projevovala na třech rovinách. Za prvé je zde „generační místo“ - termín, kterým Mannheim charakterizuje socio-strukturní, objektivní modus generace a který je analogický termínu tř́da. $\mathrm{V}$ duchu německé tradice 20. let 20. století chápal sociální místo jako osud (Schicksal), v návaznosti na Weberův pojem Klassenschicksal nebo Heideggerovo obecné užití termínu Schicksal coby předurčení individuální existence sociálně-historickými podmínkami. Čistě z hlediska definice zahrnuje „generační místo“ všechny osoby, jež jsou narozeny v určitém období na geograficky vymezeném místě. Jenže Mannheimův odkaz ke konceptu sociálního místa se nezaměřuje na distribuci šancí či zdrojů - soustředí se na strukturu př́iležitostí. Generační místo charakterizují dva druhy selektivity. Na jedné straně lidé narození ve stejném časovém období zakoušejí události, $\mathrm{k}$ nimž dochází ve stejné historické fázi, ve stejné specifické biografické fázi; dřívější nebo pozdější historické události zakoušejí v odlišné specifické biografické fázi. Například lidé narození v Německu v roce 1940 zažili druhou světovou válku v raném dětství, zatímco zkušenost raného dětství lidí narozených o deset let později vyznačovalo období obnovy a navracející se prosperity. Na druhé straně lidé narození ve stejném časovém období zakoušejí historické události v určité časové posloupnosti během svého vlastního života. Tak např́iklad lidé narození v roce 1940 zažili válku v průběhu svého dětství, obnovu v mládí, prosperitu $v$ rané dospělosti a stagnační krizi ve středním věku.

Za druhé, Mannheim dále rozlišuje mezi uvedenou strukturou zkušeností a „generační skutečnosti' “, ${ }^{3}$ to jest způsobem, jakým se zkušenosti dané generace sjednocují v její inter-

3 „O generační souvislosti tedy budeme hovořit jen tehdy, když reálné sociální a duchovní obsahy právě v oblasti uvolňování a zrodu nového vytvářejí reálné spojení [wahrhafte Verbindung] mezi jedinci, kteří se nacházejí ve stejném generačním zasazení“ (Mannheim 1952: 303; česky s. 30). „Tito jedinci byli a jsou vrstevníky spojenými generační souvislostí [Generationszusammenhang] jen proto, že mají podíl na oněch sociálních a duchovních proudech, které konstituovaly příslušný historický okamžik, a jen potud, pokud se aktivně i pasivně podílejí na vlivech, které formují novou situaci“" (1952: 304; česky s. 30).

Anglický překlad ve vydání Routledge \& Kegan Paul, 1952: „We shall therefore speak of a generation as an actuality only where a concrete bond [wahrhafte Verbindung] is created between members of a generation by their being exposed to the social and intellectual symptoms of a process of dynamic destabilization“ (Mannheim, 1952: 303). „Individuals of the same age, they were and are, however, only united [connected, German: verbunden] as an actual generation [Generationszusammenhang: ,coherence of generation'] in so far as they participate in the characteristic social and intellectual currents of their society and period, and in so far as they have an active or passive experience of the interactions of forces which made up the new situation" (1952: 304).

Všechny citace z Mannheimova textu „Otázka generací“ uvádíme podle překladu Daniely Blahutkové otištěného v tomto čísle Sociálních studii; návazně je také doplňujeme o př́ílušná čísla stran. Pro srovnání a především ve snaze upozornit na některé nejasnosti vyplývající z odlišnosti anglického překladu a německého originálu ponecháváme v poznámce vždy též anglickou verzi (viz „The Problem of Generation“, in K. Mannheim Essays on the Sociology of Knowledge. Routledge \& Kegan Paul: London, s. 276-320), již cituje Corsten ve svém textu (pozn. redakce Sociálních studii). 
pretaci. Zatímco generační místo se zaměřuje na to, jak bylo něco specifického zakoušeno, generační kontext se soustředí na to, jak kolektiv své zkušenosti uspořádává. Generační kontext proto zahrnuje jisté základní sdílené směřování, konkrétně směřování, jímž se vyznačuje většina lidí stejného věku; Mannheim toto směřování nazývá „Grundintentionen“ (základní intence) a „Gestaltungsprinzipen“ (principy výstavby). V tomto smyslu charakterizoval Helmut Schelsky (1963) osoby narozené kolem roku 1929 jako „skeptickou generaci“ a Bude (1995) popsal hnutí 60. let 20. století jako „melancholické““.

Za třetí, Mannheim rozlišuje konkrétní skupiny lidí stejného věku, kteří nejen že definují svou situaci podobným zpo̊sobem, ale také vyvíjejí podobné způsoby (re)akce ve vztahu k problémům své generace. Tyto skupiny nazývá „generačními jednotkami“. Tak se objevuje vnitřní diferenciace generačního kontextu do několika potenciálně znepřátelených či soupeřících generačních jednotek. Když vezmeme jako př́ílad hnutí 60. let, můžeme rozlišit „rockery“, „hippies“, „politické úlet’áky“ a další konkrétní skupiny.

Ústřední rys Mannheimova odstupňovaného pohledu na generace se vyjasní, nahlédneme-li na to, jak řeší problém utváření pozadi generační zkušenosti tím, že se snaží určit výjimečnost okolností, v nichž tento druh sociálního vědění může vzniknout. Klíčovými body argumentace se zde stávají dva předpoklady. Prvním z nich je ustavující priorita generačního kontextu. Druhým je význam biografické fáze mládí - nebo, jak ukážu později, adolescence:

Mládež, která je směrována stejnou historicko-aktuální problematikou, žije v jedné „generační souvislosti".

(Mannheim 1952: 304; česky s. 31)

Generační místo - synchronní zkušenost stejné kohorty se simultánní posloupností průběhu života a historických období - je vnímáno jako základní struktura „mentálních příležitostí" věkové kohorty. Avšak souvislost zkušeností těchto osob se stává skutečnou teprve v okamžiku, kdy sdílejí určité „základní intence“ a/nebo „principy výstavby“, které slouží jako orientační rámec daný jejich kolektivnímu uspořádání příležitostí ve vztahu k zakoušeným událostem. Právě proto Mannheim očekává, že existují věkové kohorty, jež nebudují či nevytvářejí sdílený rámec (nebo řád) zkušenosti.

\section{Svébyłná perspektiva rekonstruování „skutečnosti generací“}

Jestliže nyní srovnáme Mannheimovo řešení s relevantními př́klady pozdějšího sociologického výzkumu generací - s konceptem kohort (Ryder 1965, Glenn 1977, Kertzer 1983) a s konceptem prostředí (Matthes 1985, Bohnsack 1997) - zjistíme, že z různých důvodů

Mannheimův originál (německy): „Dieselbe Jugend, die an der selben historisch-aktuellen Problematik orientiert ist“ bych preložil jako „The (same) youth that is oriented at the same historicallycurrent complex of problems lives in the coherence of a generation."

Anglický překlad ve vydání Routledge \& Kegan Paul, 1952: „Youth experiencing the same concrete historical problems may be said to be part of the same actual generation"(Mannheim 1952: 304) (pozn. redakce Sociálních studii). 
žádný z těchto př́stupů nenavazuje na Mannheimův odkaz. Žádný z nich nebere na vědomí ustavující prioritu toho, jak lze generačně sdílené uspořádání zkušeností kolektivně formovat.

\subsection{Pozadí generační zkušenosti vs. podobnosti v rámci věkových kohort}

Na první pohled existují podobnosti mezi konceptem kohort a Mannheimovým pojetím „generačního místa“ a mezi konceptem prostředí a jeho myšlenkou „generačních jednotek". Věkové kohorty a generační místo jsou definovány, technicky řečeno, jako lidé, kterým se určitá událost - např́ílad narození - stala ve stejném časovém bodě. Avšak protože jde o ucelenější technický př́stup, koncept věkových kohort nevyslovuje další domněnky o specifické formě generační zkušenosti. Koncept kohort umožňuje výzkumníkovi rozlišit určité skupiny, jež jsou výsledkem měření různých úrovní. Je to tedy především nástroj sloužící k pozorování, popisu a někdy též k vysvětlení sociální změny.

Podle tohoto modelu by mohlo být dostačující jednoduše určit rozdíly mezi věkovými kohortami ve smyslu „objektivních indikátorư“, jako je úroveň vzdělání, zaměstnanecký status, míra sňatečnosti a rozvodovosti atd., změřených v určitém období jejich životů. Lze např́iklad pozorovat, že mladší kohorty v Evropě opouštějí školu, začínají pracovat, odcházejí od rodičů, uzavírají sňatky, mají první dítě atd. v pozdějším věku. „Objektivní“ př́stup k „analýze historie životních událostí“ (Blossfeld a Rohwer 1995) by ovšem zacházel se socializačním procesem jako s černou skř́ňkou. Především v retrospektivních modelech, kde nelze shromáždit subjektivní data týkající se postojů, interpretací nebo hodnotových orientací př́slušníků kohorty, není možné vyhovět Mannheimovu požadavku rekonstrukce „stratifikace zkušenosti““ (Erhebungsschichtung) jako př́ležitostní struktury zkušeností sdílených generačním místem. V tomto modelu nelze odkazovat k „vnitřni““, subjektivní, biografické časové perspektivě nebo ke zkušenosti lidí patřících $\mathrm{k}$ jedné generaci a $\mathrm{k}$ obrysům jejich specifického minulého, prítomného a budoucího horizontu. Také individuální způsoby vyrovnávání se s důležitými životními mezníky by mohly být analyzovány pouze tehdy, pokud by prokázaly objektivní, chronologické umístění v čase. Tento nedostatek lze překonat volbou striktně longitudinálního přístupu, $\mathrm{v}$ němž se osob z jedné věkové kohorty tážeme na jejich postoje k biografickým a zakoušeným historickým událostem, na interpretace a hodnocení těchto událostí a na jejich náhled na minulost, prítomnost a budoucnost. ${ }^{5}$

\subsection{Logický vs. historický čas}

Dokonce i takováto strategie uvízla $\mathrm{v}$ zajetí techničtějšího pojetí generace, především v důsledku teorie času v ní obsažené. Protože lidé se rodí kdykoli během roku, v různých dnech i hodinách, tedy neustále, neexistuje žádný systematický důvod, proč rozlišovat mezi věkovými kohortami nebo věkovými skupinami. $\mathrm{V}$ modelu kohort tak můžeme volit věkové skupiny bud' podle matematického principu využívajícího chronologického modelu času, tj. sestavovat jednotky věkových skupin zahrnující stejné množství po sobě narozených ročníků

Elderova (1974) výzkumná tradice je dobrým př́íkladem této výzkumné metody. 
(1940-9, 1950-9 atd.), nebo volit po sobě následující věkové skupiny v pravidelných intervalech (1939-41, 1949-51 atd.). Zde se zdá být smysluplné objasnit odkaz ke konceptualizaci času. Jeho výchozí bod tvoří rozdíl mezi „logickým časem“ a „historickým časem“, který zavedla Joan Robinson (1963: 23-9, 1979) ve svém pojednání o neo-klasickém modelu ekonomického růstu. Pojem „logického času“ spočívá v přehledu lineárního postupu za sebou následujících zřetelných časových bodů. Jakýkoli čas uzavřený do tohoto modelu je považován za událost danou podmínkami, které je třeba prozkoumat, v prŕípadě ekonomického vývoje podmínkami rovnováhy. Joan Robinson byla „navýsost“ přesvědčena, že skutečný historický vývoj (ekonomií) nesleduje takovéto lineární schéma. „Stavů rovnováhy“ je dosahováno v nepravidelných intervalech, pokud ovšem vůbec nastanou.

Tuto úvahu můžeme převést na případ naplnění generačního pozadí zkušenosti. Procedura modelu kohorty popsaná výše vychází z představy, která odpovídá modelu „logického času“, jak jej vyložila Joan Robinson. V modelu kohort jsou měřeny vlastnosti, které náleží skupinám osob, jež byly usouvztažněny kvůli své př́íslušnosti k určitému roku narození. Avšak tyto vlastnosti agregovaných věkových kohort měřených v pravidelných časových intervalech nutně neznamenají existenci generačně-specifického zkušenostního pozadí. Tento problém zohlednili již stoupenci kohortního přístupu. Zaznamenali, že vlastnosti naměřené u věkových kohort v určité době mohou být také zapříčiněny věkem osob, kulturními vlivy nebo socio-ekonomickými podmínkami zkoumaného období. Proto byly do výzkumného projektu zahrnuty rozdíly dané působením věku, období a kohorty (Glenn 1977: 14, 49). Je však toto rozlišování skutečně užitečné, chceme-li se držet požadavku Jane Robinson, podle kterého předpokládá utváření pevných (kolektivních) vývojových trendů myšlení $\mathrm{v}$,historickém čase“?

V jejím pojednání o „historickém čase“ hrají významnou roli tři pojmy, které Robinson sama dostatečně nevysvětluje: emergence, komplexita a sebereference.

Emergence Jestliže sledujeme konkrétní historické události, jsme často konfrontováni s kvalitativními skoky, které se objevují nepravidelně. V díle Joan Robinson lze tento vývoj vysledovat v jejím pojetí problému první akumulace. Jestliže převedeme pojem emergence na př́ipad generací, předpokládá to nahodilé objevování se generací jako historicky formovaných kolektivů. To znamená, že generace jsou výsledkem nahodilosti a že se objevují nepravidelně $\mathrm{v}$ chronologickém čase. Z tohoto důvodu musí teorie generací poskytnout základní kategorie a konceptuální schéma, které učiní viditelným (představitelným) způsob, jímž se generace vyvíjí v historickém procesu, a zároveň zaznamená obsah a význam historického období.

Komplexita Lineární pojetí času je často spojováno s představou homogenního vývoje. Avšak vznik generačního zkušenostního pozadí je závislý na interakci několika heterogenních dynamických systémů. Musíme vzít v úvahu vzájemnou souhru tři procesů, které nemohou být na sebe vzájemně redukovány. Za prvé je zde posloupnost historických událostí, jež se odehrává v rovině společnosti. Za druhé, paralelně s ní, probíhá biografický vývoj jednotlivců v rámci jejich vlastních životů. Třetím procesem, který musíme rekonstruovat, je slučování skupin stejného věku, ale možná odlišných v jiných ohledech, do jedné generace. Vezměme si např́klad hnutí šedesátých let. Ne všichni dospívající lidé přišli do kontaktu 
s tímto hnutím ve stejnou dobu a ve stejném věku. Stejně tak mu všichni nevěnovali stejnou pozornost. Pro některé bude významné po dlouhou dobu, pro jiné možná jen krátce, ale zato intenzivně, a ještě pro další krátce a pouze povrchně. Všechny tyto kombinace závisejí na tom, jak je vývoj jednotlivce $\mathrm{v}$ daných věkových skupinách propojen $\mathrm{s}$ utvářením jejich současníků jako kolektivu. Navíc soudržnost těchto dvou aspektů vývoje nelze sledovat bez ohledu na vývoj společensko-historických událostí daného období, počínaje atentátem na Kennedyho až po festival Woodstock. Avšak tyto tři procesy - proces generace, proces historického období a proces individuálního života - nejsou pouhými posloupnostmi událostí, jsou také proudy zkušeností; a v neposlední řadě také příběhy generací, historických procesů daného období či jednotlivých biografií. Ve vztahu k otázce, jak vzniká generace jako nositelka kolektivní zkušenosti, jsou všechny tyto procesy vzájemně propojeny.

Sebereference znamená, že proces je strukturován či ovlivňován očekáváními, která lidé mají ohledně možných způsobů pokračování procesu. Právě takto fungují sociální či ekonomické procesy. Lidé, kteří je provádějí, je ovlivňují svými očekáváními. Podobným způsobem je i generace formována pocitem, skrze který její př́slušníci vnímají kritéria přináležitosti. Německý sociolog Heinz Bude (1997) jej nazval „my-pocitem“ generace. Příslušníci určité generace tak nesdílejí pouze předpoklady stejného zkušenostního pozadí. Sdílejí také pocit, že ostatní př́islušníci stejné generace sdílejí podobné zkušenostní předpoklady. Nejenže mají něco společného, mají také (společný) pocit (jistý druh vědění), že mají něco společného. Tato intuitivnější reflexe společného pocitu generace je součástí pocitu sdílení kolektivního času - smyslu, který převádí můj čas na náš čas nebo čas naší generace. Čas potom není jen sledem událostí nebo pouhých časových bodů, je také perspektivou času, která je vlastní jednotlivcům a/nebo kolektivům.

\subsection{Specifické pojetí socializace skrze generační zkušenost}

Nyní se nabízí otázka: jak může být toto nahodilé objevování se komplexního a sebereferenčního času a sebe-nahlížení generace reprezentováno v sociální realitě? Kde se vlastně tato forma kolektivní sebeindentifikace (za předpokladu pozadí podobně zakoušeného času) odehrává? Některé nedávné práce německých sociologů (Bohnsack 1997, Matthes 1985, Sackmann 1991), které se této otázce věnovaly, navrhovaly analýzu utváření životních prostor mladistvých coby výrazu ,generačních jednotek“. Kultury mládeže jako životní prostory jsou považovány za „sféry konjunktivní zkušenosti“ (konjunktiver Ehrfahrungsraum), podobně jako v raných pracích Karla Mannheima (1980 [1922]). Zde je velice důležité jasně zdůraznit odlišnost Mannheimových konceptů zkušenosti; ty jsou lokalizovány nejméně na třech úrovních, což lze vnímat jako paralelu ke třem rozměrům ustavování generací jako kolektivních jevi̊.

1. Vrstvy zkušenosti jako struktura příležitostí generačního zasazeni - jenom lidé narození a vyrůstající ve stejném čase mají př́íležitost zakoušet určité události a jejich následnost současně. 
2. Shoda v určitých formativních a interpretačních principech či schématech zkušenosti osob, které př́íslušejí (či se účastní) shodné generační skutečnosti.

3. Sféra konjunktivní zkušenosti, sdílená pouze osobami, jež zakusily „existenciální svazek“, která se vztahuje pouze na ty, kdo byli skutečně účastni určitých událostí. „Tato sféra zkušenosti je... zvenčí uzavřena“ a založena na konkrétním setkávání lidí.

Podle této definice je nutné „správná místa“, fyzicky zakoušená kulturami mladistvých, odlišit od schémat zkušeností sdílených generační skutečností:

Sociální význam existence těchto formujících intencí spočívá v tom, že jejich prostřednictvím lze spojovat i prostorově oddělené jedince, kteří se nikdy nedostanou do osobního kontaktu. Zatímco příbuzné generační zasazeni je jen něčím potenciálním, generační souvislost se utváŕí participací jednotlivců stejného generačního zasazení na společném osudu a jemu přináležejících, jaksi souvisejících obsazích.

(Mannheim 1952: 306; česky s. 32)

Generační rámec zkušenosti se vymyká „sférám konjunktivní zkušenosti“ sdíleným konkrétními skupinami uspořádanými do generačních jednotek. Tito lidé, jakkoli nesdílejí konkrétní životní zkušenost, se podobají, protože jsou obeznámeni s určitými interpretačními a formativními principy vztahujícími se $\mathrm{k}$ jejich biografickému a historickému horizontu. To znamená, že sociolog zaměřující se na žité prostředí pracuje s velmi úzkým konceptem socializace. Pak však musí koncept „generační souvislosti“ vypracovat model socializace, který ukáže, jak obeznámenost mezi současníky vzniká bez odkazu na konjunktivní zkušenost předávanou v konkrétních skupinách. V sekci 4.2. se pokusím vysvětlit tuto transmisi zkušenostního pozadí odkazem na kulturní okruhy generačního diskurzu.

Vnitřní diferenciace generace do generačních jednotek se soustředí na následující problémy. Lze analýzou různých prostředí kultur mládeže dospět k rekonstrukci srovnatelných interpretačních schémat, která jsou platná pro typické prostředí (či rámec) zkušenosti mládeže jako „celku“? Není riskantní snažit se ustavit zákony a struktury sociální nerovnosti hledáním rozdílů mezi vrstvami, pohlavími, profesními či kulturními statusy osob uvnitř stejných věkových skupin? Pak je tedy třeba opustit pojetí generace jako homogenní věkové skupiny. Hovoříme-li o generačním pozadí zkušenosti, předpokládáme, že do něj mohou být zahrnuty různé věkové skupiny či specifické ,generační jednotky“. Ale Mannheimovo vysvětlení formativních principo̊n, které utvářejí generační skutečnost nejde tak daleko. Obecně řečeno, Mannheim objasňuje, že „otevřenějšíi“ formativní principy lze lépe uplatnit v rámci sociál-

6 Anglický překlad ve vydání Routledge \& Kegan Paul, 1952: „The social importance of these formative and interpretative principles is that they form a link between spatially separated individuals who may never come into personal contact at all. Whereas mere common location in a generation is of only potential significance, a generation as an actuality is constituted when similarly located contemporaries participate in a common destiny and in the ideas and concepts which are in some way bound up with its unfolding“" (Mannheim 1952: 306) (pozn. redakce Sociálních studii). 
ních procesů a že jejich kolektivní zprostředkování se děje v mládí, avšak neukazuje, jak nebo v jakých procesech se tyto principy vytvářejí.

\section{Instiłucionalizovaný životní běh, diskurzivní praktiky a kulturní cykly adolescence}

Chci rozvinout tři argumentační linie, které by měly napomoci objasnit, jak příslušníci stejné věkové kohorty získávají srovnatelné interpretace horizontu své historické situace. Za prvé se budu věnovat tvrzení, že generace vytváří takovéto srovnatelné interpretace ustavováním dominantního sémantického řádu (řádu významů) ve svých diskurzivních praktikách (4.1). Za druhé předkládám tvrzení z oblasti teorie jednání, že v období adolescence se vytvářejí ,,sociální okruhy“, které nesou sémantický řád (4.2). Za třetí se snažím dokázat výše zmíněné nahlížením adolescence jako sociálně definovaného stadia v rámci institucionalizovaného životního běhu, který zahrnuje standardizovaná období přechodu.

\subsection{Generační sémantika jako řád významu udržovaný pohromadě sdílenými kritérii interpretace a vyjádření}

Začněme diskurzivně-teoretickým základem Mannheimova konceptu základních intencí a formativních principů. Jeho hlavní argument je následující.

Základní intence [Grundintentionen] formující principy jsou to nejpodstatnější i u každého tradování, nebot' jen ony působí opravdu socializačně [denn nur diese wirken wahrhaft vergesellschafend]; a, což je možná ještě důležitější, jsou opravdu předavatelné.

(Mannheim 1952: 305, česky s. 31) ${ }^{7}$

Mannheim více nevyjasňuje, co rozumí „praxí“. Ústředním bodem je pro něj prostě to, že formativní principy jsou obecnější, a tím také účinnější či lépe využitelné v dalších sociálních aktivitách. Zde se podle všeho dostáváme k mezím Mannheimovy sociologie vědění. Jane Pilcher (1994) upozornila na toto omezení s využitím argumentů C. W. Millse (1963) a Tima Danta (1991), které odkazují k sociálně-psychologické provázanosti vědění, jazyka a diskurzu. Millsova kritika (1963) většiny sociologií vědění, včetně Mannheimovy, poukazuje na nedostatečnou konceptualizaci souvislosti vznikající mezi sociálně-kognitivními procesy a sociálními podmínkami. Jedním z př́kladů této slabiny je vztah mezi zasazením generací jako experimentální struktury příležitostí a formativními principy. Mills zavádí dva přemost'ující argumenty. Prvním je Meadův koncept „generalizovaného druhého“. Jestliže předpokládáme, že aktéři jsou schopni zaujímat postoj „generalizovaného druhého“, mohou

7 Anglický překlad ve vydání Routledge \& Kegan Paul, 1952: „Fundamental integrative attitudes (Grundintentionen, i.e. basic intentions) and formative principles are also all-important in the handing down of every tradition, firstly because they alone can bind groups together (denn nur diese wirken wahrhaft vergesellschaftend) and secondly, perhaps even more importantly, because they alone are really capable of becoming the basis of continuing practice“ (Mannheim 1952: 305) (pozn. redakce Sociálních studii). 
být formativní principy nahlíženy jako očekávání předpokládaného hlediska nebo postoje „generalizovaného druhého“. Základními intencemi či formativními principy by pak byla kritéria platnosti, která jsou sdílená (nebo prostě předjímaná jako dominantní očekávání) kolektivem generace. Za druhé, Mills si všímá překrývání se sociálních dimenzí jazyka se základní relevancí jazyka pro prožívání a myšlení, pro kognitivní procesy obecně. Shrneme-li jeho argumenty, tvrdí, že můžeme rekonstruovat, jak lidé nebo kolektivy myslí, podle způsobu užívání jejich slovní zásoby, včetně způsobu vyjadřování významových nuancí (viz také Rorty 1989).

V kolektivním uživání znaků a jazyka jsme našli prostředkující rovinu mezi „sociálním zasazením“ a „sociálními zkušenostmi“. Zatím však neumíme vysvětlit, jak určité kolektivní užití znaků/jazyka zvítězí nad ostatními. Pro vyrovnání se s tímto problémem Tim Dant navrhuje zavést pojem „diskurzü“ jako empirického místa (sociálního) vědění, „nebot’ diskurzivní praxe zahrnuje sociální jednání, které lze identifikovat v čase a místě“ (Dant 1991: 31). Jeho návrh je inspirativní hned dvojím způsobem. Na jedné straně sociálním vědám otevírá možnost identifikovat vědění, zkušenost, vzorce myšlení a interpretace - něco jako Mannheimovy „základní intence“ a „formativní principy“. Na druhé straně jasně ríká, že identifikace vzorců interpretace a platnosti v sociálních procesech závisí na jejich lokalizaci v diskurzivních praktikách. Nyní můžeme dát prvotní obecnou odpověd’ na základní otázku, jak je pro generace jako kolektivy možné se identifikovat a lokalizovat $\mathrm{v}$ historických procesech, konkrétně za pomoci tematizace sebe sama, identifikace svých vzorců interpretace a potvrzování platnosti kolektivní zkušenosti v diskurzech.

\subsection{Generační sémantika a kulturní okruh generace}

Avšak tato odpověd' vyvolává další otázky. Kde, v jakých diskurzivních praktikách se kolektivní sebeidentifikace vyvíjí? Jak tato kolektivní sebeidentifikace funguje jako kolektivní sebe-tematizace? Abychom tento proces kolektivního potvrzení „formativních principů“ a „základních intencí“ trochu zpřesnili, představím koncept historické sémantiky Niklase Luhmanna (1980) a Reinharda Kosellecka (1969). Jde o zachování témat či námětů v komunikaci jejich zdůrazněním a užíáním „souboru pravidel“, která obsahují instrukce, jak se zdůrazněnými tématy v komunikaci zacházet. $\mathrm{Z}$ hlediska spíše hermeneutického a z hlediska lingvistické pragmatiky lze historickou sémantiku definovat jako smysluplně propojená kritéria interpretace a artikulace komunikačních témat. Na rozdíl od Luhmannova systémověteoretického prrístupu se držím vysvětlení komunikace a historické sémantiky z teorie jednání. $\mathrm{K}$ tomu je nutné určit „nositele“ historické sémantiky, kteří prosazují zvolená kritéria interpretace a artikulace $\mathrm{v}$ kolektivním kontextu svým komunikativním jednáním. $\mathrm{V}$ př́padě generací pocházejí tito aktéři z kolektivu omezených věkových kohort, přičemž je důležité uvědomit si, jak je konceptualizována kauzalita tohoto procesu. Ukázal jsem, že věkové kohorty jako generační zasazení nedokáží vysvětlit vznik generační skutečnosti. Jak zdůraznil Marx (1973 [1857-8]), historický vývoj musíme objasnit tak, že začneme u vzniku historicky vyvinuté formy. To znamená, že sémantika - která zahrnuje kolektivně ustavená kritéria interpretace a artikulace určitých témat - naznačuje proces historické krystalizace; nikoli pouze příčiny či koincidence. Kolektiv představující většinu nějaké věkové skupiny ustaví soubor 
smysluplně propojených kritérií interpretace a artikulace svých témat. Avšak krystalizace kolektivně sdílených kritérií vede k prvním omezením kolektivu. Komunikace o určitých tématech, která do komunikačního procesu zavádí kritéria jejich interpretace a artikulace, funguje jako proces srážení určitých věkových skupin - jako forma, která je váže dohromady. Tento proces nazývám historickým srážením sociálního okruhu nebo, v našem př́ípadě, , kulturniho okruhu" generace.

Pojem „kulturní okruh“ by měl být odlišen od konkrétních skupin. „Kulturní okruhy“ jsou zde definovány jako lidé, kteří si spontánně všímají toho, že jiní lidé používají určitá kritéria interpretace a artikulace témat podobným způsobem jako oni sami, přestože se nikdy v životě nepotkali. V př́ípadě generačně vytvořených „kulturních okruhü“ tak existuje vyšší pravděpodobnost, že u lidí, kteří patř́ ke stejné věkové skupině, bude možné zaznamenat podobné způsoby užívání kritérí interpretace a artikulace některých témat. To lze vysvětlit tím, že lidé náležející ke stejné věkové skupině, vykazují vyšší pravděpodobnost zaujímání srovnatelných stanovisek a hledisek v diskurzivních praktikách, do nichž se zapojují. Tato hlediska jsou vzhledem $\mathrm{k}$ sociální standardizaci životního běhu poznamenána a strukturována věkem. Jeden $z$ důležitých prvků zde představuje to, že lidé v životní fázi adolescence mohou potkat generačně stejně zasazené lidi s podobnými stanovisky v mnoha, někdy téměř všech, sociálních kontextech, do nichž se dostávají. Věk je proto významnou sociálně podmíněnou odlišností. $V$ prrechodu od mládí $\mathrm{k}$ dospělosti potkávají adolescenti jiné adolescenty: když opouštějí školu a začínají pracovat, nebo když odcházejí od rodičů a zařizují si vlastní domov, či když chodí na schůzky a navazují vlastní důvěrné vztahy, jako jsou prátelství a láska. Současné a nahodile probíhající styky mezi lidmi stejného věku v různých sociálních kontextech jsou vnímány jako „kulturní okruh“ generace, který poprvé vykrystalizuje v přechodovém životním období adolescence. Tento kulturní okruh simultánních a následných styků je nositelem generační sémantiky.

\subsection{Moderní konstrukce adolescence}

Dosavadní argumentace konkretizovala Mannheimovo hledisko skutečnosti generací. Avšak stále zbývá vysvětlit, proč je „,v̌̌k“ adolescence tak důležitý pro krystalizaci generačního sebepojetí. K tomuto účelu zavádím pojem sociální konstrukce institucionalizovaného a standardizovaného životního běhu moderního člověka (Kohli 1985, Meyer 1986). „Institucionalizace životního běhu“ se děje na dvou rovinách. První rovina odkazuje k pravděpodobnosti, že specifické životní přechody nastanou v určitém věku a ve standardní posloupnosti. Standardizace životního přechodu je do značné míry di̊sledkem vládních regulací týkajících se vzdělávání a zaměstnávání, ale také zákonů, které zavádějí jistá pravidla týkající se věku (uzákoněná dospělost, minimální věk pro pohlavní styk, sňatek, návštěvu veřejného domu nebo diskotéky, noční život apod.; viz také Mayer a Schöpflin 1989). Na druhé rovině jsou životní období poznamenána kulturními definicemi věku, např́klad soubory očekávání a konvencí uplatňovanými na lidi určitého věku. V následujícím pojednání budu předpokládat dvě obecná tvrzení týkající se moderních společností, jmenovitě, že (a) lze zhruba odlišit trri životní stadia: dětství, dospělost a stáří a že (b) existují rozdílné, na věku závislé stupně (individuální) osobní odpovědnosti. 
Na základě těchto předpokladů mohu definovat adolescenci jako biografické období pozdního mládí (konec dětství) a rané dospělosti. Což znamená, že životní období adolescence vyznačuje zkušenost přebírání odpovědnosti za sebe sama, spojená s úsilím vypořádat se s formativními principy zkušenosti a aktivního vyjádření. Erikson (1980) definoval tento specifický vzorec požadavků kladených na já jako „moratorium“. Adolescence, takto pojatá jako základní struktura očekávání, může být chápaná jako prověrka toho, jak dalece se naplňuje moderní požadavek já - vytvářet identitu primárně jako osobně vypracovanou definici sebe sama. Tato struktura požadavku je založena na odlišnosti mezi sociální a osobní identitou. Sociálně ustavené konvenční způsoby definování já, jako jsou rolová očekávání, nejsou dostatečné ve vztahu k ústřednímu požadavku kladenému na moderní já, kterým je vytvoření vlastního obrazu své osobnosti. Ralph Turner (1976) hovořil o hledání „skutečného já“ coby kódu autentičnosti, jejž interpretuje jako historický proces „od instituce k impulsu“. Ale do jaké míry se tyto procesy osobní sebe-definice zpětně podřizují sociálně přijatým kritériím ověřování? Jestliže je tedy rozlišování mezi osobní a sociální identitou ve skutečnosti v komunikaci tlumeno, znamená to, že existují kritéria ověřování v př́padě aktérů, kteří svou sebe-interpretaci převzali z konvenčních obrazů individuality. Zmíněná sociálně přijatá či předpokládaná kritéria ověřování nepředepisují specifickou podobu či obsah konstrukce já u jednotlivých aktérů, ale pouze váhu „břemene“ úspěšné sebe-interpretace, které musí aktéři nést. Tak si můžeme být jisti, že ne každá požadovaná definice sebe sama bude sociálně přijata. Proto mohou kritéria interpretace a artikulace vyvinutá v generačních diskurzech fungovat jako kolektivně sebe-organizovaná vodítka slad'ování osobní a sociální identity. Tyto diskurzy v rámci kultur mládeže také zahrnují spojení s aktuální historickou zkušeností a s biografickými časovými hledisky adolescentů. Z těchto důvodů nabízí generační sémantika vodicí kritéria pro interpretaci a artikulaci dvou problémových oblastí v rámci biografického času adolescence:

1. specifické očekávání tohoto životního období, že se vytvoří individuální osobní identita;

2. ustavení pevných spojení mezi touto sebe-definicí a skutečným obsahem a interpretací konkrétního biografického a socio-historického prostředí.

Uvnitř tohoto diskurzivního rámce budou během adolescence přijata určitá kritéria interpretace a artikulace, nebot' (a) mohou být rozpoznána v různých kontextech života adolescentů a (b) mohou se stát trvalým vzorcem orientace v měnících se situacích, (c) s jehož pomocí mohou příslušníci (mladé) generace rozeznávat svůj typický způsob života.

Vezměme v úvahu jeden př́klad. V evropském sociálním výzkumu generací byly věkové kohorty narozené v letech 1955 až 1967 (především 1957-64) - v Německu šlo o takzvanou „mládež sedmdesátého osmého“ (Mohr 1992) - označovány jako „odložená“ generace (Becker 1992, 1993; Mayer 1993), což odkazovalo ke vzorci jejich přechodu od mládí k dospělosti. Diagnóza odkladu je doprovázena citlivostí k rizikům, základním generačním typem interpretace a artikulace, který lze identifikovat v různých kontextech životů těchto osob. Jedním z nich je obava z globálních problémů a rizik, například užití a zneužití jaderné energie, ekologických krizí či neúměrně rostoucí světové populace, včetně mravního pohor- 
šení nad hladověním dětí; tj. z generačního diskurzu, který se týkal obecného historického pozadí této věkové kohorty. Dalším kontextem je zvýšená citlivost ke specifickým biografickým rizikům, jako je utváŕení časných závazků $\mathrm{v}$ profesní kariéře nebo budování důvěrných vztahů, jež vedla Ulricha Oevermanna (1988) k vyslovení diagnózy Verweigerung der Lebenspraxis (neochota přijmout praktickou odpovědnost za svůj vlastní život). Objevuje se pojem „skutečného já“ (Turner 1976), který přenáší „pozornost“ na své vlastní fungování, alespoň co se týče biografických a historických procesů, jež jsou interpretovány jako dlouhodobé a obnášející nebezpečí v podobě skrytých vedlejších důsledků. Tuto specifickou pozornost zaměřenou na sebe sama lze chápat jako kód osobní identity generace „sdělující úzkost“ (Luhmann 1989) v „rizikové společnosti“ (Beck 1992); lze ji rozpoznat podle toho, jak př́slušníci generace interpretují a artikulují své vlastní i cizí pohyby v diskurzivních praktikách.

Toto teoretické přemostění nám umožní nahlédnout, jak se v kulturních okruzích věkových skupin adolescentů vyvíjí generační sémantika. Základními prvky této sémantiky jsou kritéria diskurzivního uchopení témat, která nabývají na síle $\mathrm{v}$ interpretačním potvrzování platnosti („vigencias“) v komunikačních kontextech generace. První krok vysvětluje historické budování generace jako endogenní proces.

\section{Endogenní čas generačního diskurzu}

\subsection{Historické trvání a velikost generací}

Objasněním toho, jak se generace dokáží identifikovat jako kolektivy v diskuzru, ještě neustavíme vysvětlující kritéria pro vymezení historické následnosti generací. Jak lze vysvětlit velikost věkových skupin? Proč jsou někteří jednotlivci př́liš mladí a jiní př́liš staří, někteří narození př́liš brzy a někteří prŕliš pozdě na to, aby patřili do určité generace? Můžeme zvážit dva následující typy vysvětlení: za prvé, vymezení generace lze vysvětlit exogenně výskytem ojedinělých historických událostí (atentáty, krachy na burze, „černé pátky“) nebo určitého historického vývoje (války, prosperita, kulturní liberalizace); za druhé, časové mezníky generace lze vysvětlit endogenně konkrétní rekonstrukcí jejího vzniku.

Oba typy vysvětlení jsou samy o sobě slabé. $Z$ tohoto důvodu navrhuji chápat prríčiny, jako jsou exogenní historické události či časový vývoj, jako nedílně spjaté s endogenní dynamikou geneze historické generace. To se stane zřejmým, podíváme-li se na generační zasazení jako na př́ležitostní strukturu zakoušení historických procesů $\mathrm{v}$ určitém biografickém období. Pouze některé věkové skupiny mohou zažít určitý historický vývoj nebo událost v období adolescence; jiné věkové skupiny jsou na to př́lišs staré, nebo př́liš mladé. Tato koincidence není ovšem pouhou „náhodou“ překrytí historického okamžiku s biografickým časem. Oba současně se vyskytující fakty jsou výsledkem sociálních procesů kolektivní interpretace. Jisté události nebo jistá dění musí být zvýznamněny jako historicky relevantní, přičemž časový rozměr těchto událostí a vývoje podléhá interpretacím a konvencím zapojených aktérů nebo kolektivů. Určitá období individuální biografie je následně třeba sociálně platně interpretovat jako ,adolescenci“, tj. fázi nalézání osobní identity. Oba tyto fakty jsou závislé na interpretaci v kulturních okruzích kolektivních aktérů. To znamená, že když generace ignoruje relevantní 
téma $\mathrm{v}$ jistém historickém období, toto prriřazení je zároveň důsledkem její vlastní sebe-tematizace jako generace, nebot' kolektivní sebe-definice je důsledkem zdůrazňování historického prostředí. Vidíme zde propojení dynamiky dvou selektivních procesů:

1. specifické období (události, vývoj) musí být de facto interpretováno jako relevantní historický čas, s určitým časovým vymezením;

2. specifickému souboru věkových skupin musí být de facto přiřazeno (nebo si samy musí prriřadit) status bytí $\mathrm{v}$ přechodu $\mathrm{z}$ mládí do dospělosti.

Diskurzivní utváření generace závisí na průběhu obou těchto procesů. Navíc diskurzivní utváření generace tím, že zdůrazňuje téma určitého historického vývoje, je procesem, který se sám děje v čase.

Můžeme se tedy ptát, jestli určité věkové skupiny budou pro tento proces ústředními, nebot' jej doprovázejí od počátku do konce. To zároveň znamená, že některé věkové skupiny mohou být př̀edchůdci generace a jiné budou do období adolescence vstupovat teprve tehdy, když už se proces bude vytrácet. Generace - kolektivně utvářené v sociálně demonstrovaném období adolescence - jsou časově omezené. Objevují se během omezeného historického času a obsáhnou omezený soubor věkových skupin narozených ve stejném období. Lidé narození na hranici těchto věkových skupin spadnou někam mezi, to jest virtuálně jsou př́slušníky předcházející a nastupující generace. Nezformují střed své vlastní generace. Krystalizační proces generace odehrávající se $\mathrm{v}$ průběhu kolektivní zkušenosti adolescence má dva kulminační body:

1. prosazení sémantiky v rámci omezeného počtu věkových skupin narozených ve stejném období;

2. moment, kdy generace,,pře-rostou“, tj. kolektivní přepadávání generačních protagonistů do dalšího stadia v životní dráze.

Určitá generace a její kritéria tak ztrácejí věrohodnost tváŕí v tvář generaci nastupující. Nejprve chvíli trvá, než se generační sémantika objeví v jejích diskurzivních vztazích a vyrýsuje kulturní okruhy, které budou fungovat jako nositelé této sémantiky. Přijetí takové sémantiky se ustaví, jakmile dokáže generace dočasně artikulovat interpretační síly (,vigencias") svých nových myšlenek. Avšak od tohoto okamžiku se zvyšuje šance, že nastupující věkové skupiny budou hledat alternativní vzorce interpretace. Proces krystalizace a ,pře-růstání“ mladé (adolescentní) generace má dva další rozměry v zasazení generace v mezigeneračním diskurzu a následně v kolektivním stárnutí generace.

\subsection{Vzłahy mezi generacemi: „polyfonně uspořádaná časová hlediska“}

Jedním z ustavujících momentů generace je to, že může být odlišena od generací jiných. Na první pohled se zdá, že jde o důsledek věkových rozdílů nebo věkových vrstev společnosti, ale opět je potřeba zeptat se přesněji, jak se takové „věkové vrstvy“ utvářejí a jak dojde $\mathrm{k}$ tomu, že je generace zasazena do určité vrstvy. Z pohledu výše nastíněného teoretického 
rámce rozvíjíme ve vztahu $\mathrm{k}$ tomuto problému dva základní předpoklady. Struktura „věkových vrstev“ či „koexistující“ a „vzájemně propojené“ generace jsou výsledkem historie diskurzů. Na společné konstrukci se podílí endogenní diskurzivní proces specifické generace a vzájemně propojený diskurz koexistujících generací.

První předpoklad odkazuje ke způsobu identifikace a vysvětlování historických vrcholů, v nichž se jedna generace posouvá z určitého stadia a jiná následuje. Druhý se ptá, jak jedna generace rozpozná druhou jako odlišnou, jak na sebe navzájem reagují a jak tyto reciproční reakce pohánějí strrídání generací. Jestliže chápeme životní běh jako stř̌́dání kulturně definovaných stadií, fází nebo biografických období, můžeme předpokládat, že do těchto fází vstupují a z nich vystupují generace jako kolektivy. Toto kolektivní střídání skrze životní fáze je vyvažováno mezigeneračním diskurzem. Mezigenerační diskurz je nutný k označení zlomových bodů generačního stř́dání, k určení historických okamžiků, kdy „stará“ generace v určitém životním stadiu mizí a je nahrazena generací novou.

Opět lze vzít jako př́klad krystalizaci generace adolescentů. Jak bylo řečeno výše, stanovení určitých uznávaných vzorců interpretace a artikulace jako typických pro jednu generaci je prvním krokem k mezigeneračnímu diskurzu. Umožňuje sociálním aktérům sdílet (vlastní) kolektivní hlediska v diskurzu; umožňuje jim označit vlastní pozici v diskurzu a odlišit ji od stanovisek jiných, vnímaných jako difúzní. Avšak v př́padě adolescentních generací jsou pro vymezení důležité dva další generační kolektivy: generace rodičů a předcházející generace adolescentů. $\mathrm{Z}$ hlediska adolescentních dětí symbolizuje generace rodičů (která není sama o sobě generací) $)^{8}$ problém nesouhlasu a hledání své vlastní cesty, zatímco předchozí generace adolescentů představuje soupeřící pojetí identity, které je třeba si podrobit.

Jestliže tedy platí, že během adolescence lidé docházejí ke generačně souměřitelné definici problémů pro různé životní kontexty, pak tak činí v protikladu nebo v soutěži s jinými věkovými skupinami. Tento fakt ozřejmuje polyfonně ,uspořádaná časová hlediska“ (Pinder 1926, Mannheim 1952) souběžně existujících generací. V různých životních kontextech budou adolescenti potkávat jiné adolescenty a lidi různých věkových skupin, ale proporčně se tyto věkové skupiny mohou velice lišit. To je hlavní důvod toho, proč je pro generaci tak důležité, aby okamžitě rozpoznala specifický typ vyjádření své vlastní generace $\mathrm{v}$ mnohočetném světě mezigeneračních vztahů, a mohla tak zasadit své vlastní vidění času i světa do nesourodé posloupnosti situací, v nichž se souběžně vyskytují zcela odlišná časová hlediska i světonázory. Rozhodným momentem úspěchu vznikající generace je, když prosadí zavedení nového tématu, a tím získá možnost přetvořit strukturu mezigeneračního diskurzu.

\subsection{Období stárnutí generace}

Generace nesdílejí pouze stadium adolescence, ale také další životní fáze: dospělost a stáŕí. Pojem „přestárlé“ generace v období adolescence objasňuje, jak institucionalizované ukazatele věku (nebo životních stadií) nutí jednotlivce, jako kolektiv generací, aby proměnili svou „identitu“. Kolektivní stárnutí generace tak znamená též kolektivní učení. Diskurzivní krystalizace základních intencí a formativních principů vyjádření v adolescenci je následováno

8 Generace rodičů nejsou homogenní věkové ani rodičovské kohorty. 
kolektivním vstupem do další životní fáze. V této další fázi musí být osvojené generační způsoby životních praktik přehodnoceny s ohledem na to, které jejich prvky lze zachovat a které je nutné pozměnit.

Na prríkladě „odložené“ a „na rizika citlivé“ generace roku 1978 to znamená ptát se, jak naleznou odpověd' na problém dospělého života - praktické přebírání odpovědnosti v rámci svého generačního názorového rámce „odkládání odpovědnosti“ neboli „prokrastinace“" (viz s. 58-59).

\section{Závěr}

Mým cílem bylo objasnit nedopracovaný odkaz Mannheimova sociologického konceptu generací - specifický rozměr „generační skutečnosti“. Navrhl jsem rekonstruovat jeho pojetí formativních principů objevujících se v mládí v podobě diskurzivních praktik kulturních kruhů generačních věkových skupin. Tímto způsobem je možné „modelovat“ historickou krystalizaci generační sémantiky, jež obsahuje kritéria interpretace a vyjádření, která jednotlivcům nebo vrstvám adolescentů umožní rozeznat svůj vlastní způsob chápání sebe sama a svého světa. $V$ pozadí této generační sebe-tematizace $\mathrm{v}$ historickém čase se spouští endogenní proces, který je třeba brát v úvahu vždy, když se snažíme historicky (časově) vymezit generaci, polyfonně uspořádaná časová hlediska mezigeneračních vztahů a časová schémata kolektivního stárnutí generace. V tomto článku jsem pouze rozvinul teoretickou dimenzi problému. Některé specifické otázky tak zůstávají stále otevřené. Tvrdím však, že řády času(ů), které jsou spojeny s kolektivním jevem generace, se v konečném důsledku („konečné významy“: Bloor 1997) vyvinuly prostřednictvím diskurzu generací. Tento vývoj „konečných významư“ doby v generačním diskurzu může být rekonstruován pouze empiricky - př́pad od př́ípadu. Proto je třeba studovat, jak ze zkušenosti společně prožitého mládí získávají atributy „má generace“ či „naše doba“ pevnou sociální platnost a stávají se obecnými aspekty identifikace v diskurzivních praktikách. Jen tak se dopátráme (generaci vlastního) popisu zkušenostního horizontu, s jehož pomocí generace stárne a vztahuje se k ostatním.

Přeložila Jolana Navrátilová

\section{Literatura}

Alwin, D. F.; Cohen, R. L.; Newcomb, T. M. 1991. Political Attitudes over the Life Span. The Bennington Women after Fifty Years. Madison, WI: University of Wisconsin Press.

Beck, U. 1992. Risk Society: Towards a New Modernity. London: Sage.

Beck, U. 1997. „The Social Morals of an Individual Life.“ Cultural Values, 1: 118-26.

Beck, U.; Giddens, A.; Lash, S. 1994. Reflexive Modernisation: Politics, Tradition and Aesthetics in the Modern Social Order. Cambridge: Polity Press.

Becker, H. (ed.) 1992. Dynamics of Cohort and Generations Research, Proceedings of a Symposium, 12-14 December 1991, University of Utrecht. Amsterdam: Thesis Publishers.

Becker, H. (ed.) 1993. Solidarity of Generations: Demographic, Economic and Social Change, and its Consequences, Proceedings of a Symposium, 7-8 April 1993, University of Utrecht. Amsterdam: Thesis publishers. 
Becker, R. 1994. „Intergenerationale Mobilität im Lebensverlauf, oder: Ist der öffentliche Dienst ein Mobilitätskanal zwischen Generationen?" Kölner Zeitschrift für Soziologie und Sozialpsychologie, 46: 597-618.

Bloor, D. 1997. Wittgenstein: Rules and Institutions. London: Routledge.

Blossfeld, H. P.; Rohwer, G. 1995. Techniques of Event History Modeling. New Approaches to Causal Analysis. Mahwah, NJ: Erlbaum.

Bodnar, J. 1996. „Generational Memory in an American Town.“ Journal of Interdisciplinary History, 26: 619-37.

Bohnsack, R. 1997. „Adoleszenz, Aktionismus und die Emergenz von Milieus. Eine Ethnographie von Hooligan-Gruppen und Rockbands.“ Zeitschrift für Sozialisationsforschung und Erziehungssoziologie, 17: 3-18.

Braungart, R.; Braungart, M. M. 1986. „Life-Course and Generational Politics.“ Annual Review of Sociology, 12: 205-31.

Bude, H. 1995. Das Altern einer Generation. Die Jahrgänge 1938-1948. Frankfurt a. M.: Suhrkamp.

Bude, H. 1997. „Die Wir-Schicht der Generation.“ Berliner Journal für Soziologie, 7: 197-204.

Coleman, J. 1995. „Rights and Interests: Raising the Next Generation.“ American Sociological Review, 60: 782-3.

Corsten, M. 1998. „Between Constructivism and Realism: Searle’s Theory of the Construction of Social Reality." Philosophy of the Social Sciences, 28: 102-21.

Dant, T. 1991. Knowledge, Ideology and Discourse: A Sociological Perspective. London: Routledge.

Eisenstadt, S. N. 1956. From Generation to Generation. Glencoe, IL: The Free Press.

Elder, G. 1974. Children of Great Depression: Social Change in Life Experience. Chicago: University of Chicago Press.

Erikson, E. H. 1980. Identity and the Life Cycle. New York: Norton.

Glenn, N. D. 1977. Cohort Analysis. Beverly Hills, CA: Sage.

Hill, K.; Moreno, D. 1996. „Second-Generation Cubans.“ Hispanic Journal of Behavioral Sciences, 18: 175-93.

Kertzer, D. E. 1983. „Generation as a Sociological Problem.“ Annual Review of Sociology, 9: $125-49$.

Kettler, D.; Meja, V.; Stehr, N. 1984. Karl Mannheim. Chichester: Ellis Horwood.

Kohli, M. 1985. „Die Institutionalisierung des Lebenslaufs.“ Kölner Zeitschrift für Soziologie und Sozialpsychologie, 37: 1-29.

Kohli, M. 1996. The Problems of Generations: Family, Economy, Politics. Public Lectures No. 14. Collegium Budapest: Institute for Advanced Study.

Koselleck, R. 1969. Kritik und Krise: Ein Beitrag zur Pathogenese der bürgerlichen Welt. Freiburg/Br.: Alber.

Lang, K.; Lang, G. E.; Kepplinger, H. M.; Ehmig, S. 1993. „Collective Memory and Political Generations: A Survey of German Journalists.“ Political Communication, 10: 211-29.

Longhurst, B. 1989. Karl Mannheim and the Contemporary Sociology of Knowledge. Basingstoke: Macmillan Press. 
Luhmann, N. 1980. Gesellschaftsstruktur und Semantik: Studien zur Wissenssoziologie der modernen Gesellschaft, Vol. 1. Frankfurt a. M.: Suhrkamp.

Luhmann, N. 1989. Ecological Communication. Chicago: University of Chicago Press.

Mannheim, K. 1952. „The Problem of Generation.“ In K. Mannheim Essays on the Sociology of Knowledge. London: Routledge \& Kegan Paul [1. německé vydání 1928, Kölne Vierjahreshuafte für Soziologie, 157-85, 309-30], s. 276-320. Český překlad Sociální studia 1-2/2007, s. 11-44.

Mannheim, K. 1980. Strukturen des Denkens. Frankfurt a. M.: Suhrkamp [posmrtné vydání, napsáno 1922].

Marx, K. 1973. Foundations of the Critique of Political Economy: Rough draft. Harmondsworth: Penguin Books [německé vydání: Kritik der politischen Ökonomie: Rohentwurf 1857-1858, Frankfurt a.M.: Europäische Verlagsanstalt, 1969].

Matthes, J. 1985. „Karl Mannheims ,Das Problem der Generationen“, - neu gelesen Generationen - ,Gruppen“ oder ,gesellschaftliche Regelungen von Zeitlichkeit“?" Zeitschrift für Soziologie, 14: 363-72.

Mayer, K. U. 1993. „The Postponed Generation: Economic, Political, Social and Cultural Determinants of Changes in Life Course Regime.“ In H. A. Becker, P. L. J. Hermkens (eds.) Solidarity of Generations. Amsterdam: Thesis Publications, s. 47-69.

Mayer, K. U.; Schöpflin, U. 1989. „The State and the Life Course.“ Annual Review of Sociology, 15: 187-209.

Meyer, J. W. 1986. „Self and the Life Course: Institutionalisation and its Effects.“ In A. Soerensen, F. Weinert a L. R. Sherrod (eds.) Human Development and the Life Course. Hillsdale, NJ: Erlbaum, s. 199-216.

Mills, C. W. 1963. Power, Politics and People. The Collected Essays of C. Wright Mills, ed. and intro. Irving Louis Horowitz. New York: Oxford University Press.

Mohr, R. 1992. Zaungäste: die Generation, die nach der Revolte kam. Frankfurt a. M.: S. Fischer.

Morgan, G. D. 1994. Tilman C. Cothran: Second Generation Sociologist. Bristol: Wyndham Hall Press.

Oevermann, U. 1988. „Eine exemplarische Fallrekonstruktion zum Typus versozialwissenschaftlichter Identitätsformation.“ In H.-G. Brose a B. Hildenbrand (eds.) Vom Ende des Individuums zur Individualität ohne Ende. Opladen: Leske \& Budrich, s. 243-86.

Pilcher, J. 1994. „Mannheim’s Sociology of Generations: An Undervalued Legacy.“ American Journal of Sociology, 4: 481-95.

Pinder, W. 1926. Das Problem der Generation in der Kunstgeschichte Europas. Berlin: Frankfurter Verlagsanstalt.

Preston, W. T. 1927. My Generation of Politics and Politicians. Toronto: Rose.

Rintala, M. 1962. Three Generations: The Extreme Right Wing in Finnish Politics. Bloomington: Indiana University Press.

Robinson, J. 1963. „A Model of Accumulation.“ In J. Robinson (ed.) Essays in theTheory of Economic Growth. London: Macmillan \& Co, s. 22-87.

Robinson, J. 1979. „History versus Equilibrium.“ In J. Robinson (ed.) Collected Economic Papers, Vol. 5. Oxford: Blackwell, s. 48-59. 
Rorty, R. 1989. Contingency, Irony, and Solidarity. Cambridge: Cambridge University Press. Ryder, N. 1965. „The Cohort as a Concept in the Study of Social Change.“ American Sociological Review, 30: 843-61.

Ryder, N. 1980. The Cohort Approach: Essays in the Measurement of Temporal Variations in Demographic Behavior. New York: Arno Press.

Sackmann, R. 1991. „Das Deutungsmuster, Generation“ ““ In M. Meuser, R. Sackmann (eds.) Analyse sozialer Deutungsmuster. Pfaffenweiler: Centaurus, s. 199-215.

Schelsky, H. 1963. Die skeptische Generation. Eine Soziologie der deutschen Jugend. Düsseldorf: Diederichs.

Schuman, H.; Scott, J. 1989. „Generations and Collective Memories.“ American Sociological Review, 54: 359-81.

Schuman, H.; Belli, R. F.; Bischoping, K. 1997. „The Generational Basis of Historical Knowledge.“ In J. W. Pennebaker, D. Paez, B. Rimé (eds.) Collective Memory of Political Events. Social Psychological Perspectives. Mahwah, NJ: Erlbaum.

Searle, J. 1995. The Construction of Social Reality. New York: The Free Press.

Turner, R. 1976. „The Real Self: From Institution to Impulse.“ American Journal of Sociology, 81: 989-1016.

Van den Broek, A. 1994. „Cohorten zonder generaties. Cohortvervanging en generatievorming in Nederland." Sociologische Gids, 41: 346-71.

Van Wel, F. 1994. „A Culture Gap between the Generations? Social Influences on Youth Cultural Style." International Journal of Adolescence and Youth, 4: 211-28.

Zuravin, S., McMillen, C., DePanfilis, D., Risley-Curtiss, C. 1996. „The Intergenerational Cycle of Child Maltreatment: Continuity versus Discontinuity.“ Journal of Interpersonal Violence, 11: 315-34.

\section{Autor}

Michael Corsten studoval na Univerzität Marburg a Freie Universität Berlin. Byl přidruženým výzkumníkem Max-Planck-Institut für Bildungsforschung v Berlíně, kde koordinoval projekty zabývající se změnami socializace zaměstnanců v sektoru služeb. V současnosti vyučuje na Friedrich Schiller Universiät Jena všeobecnou a teoretickou sociologii. Publikuje texty v angličtině i němčině, mezi jeho hlavní díla patří: Das Ich und Die Liebe (Opladen: Leske \& Budrich, 1993), Die Kultivierung beruflicher Handlungsstile (Frankfurt am Main: Campus, 1998) a Die Gerechtigkeit der Gesellschaft (s Rosou Hartmut a Ralphem Schraderem; Wiesbaden: Verlag für Sozialwissenschaften, 2005). Kontakt: Michael.Corsten@uni-jena.de 